\title{
Skeptischer Gedanken
}

福井王夫

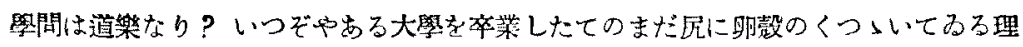

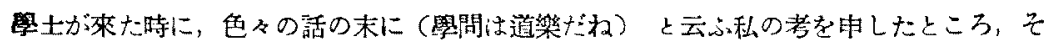
の累は少し色をなしてそれは云ひ過でしやうと云つた。けれども私の「眊問は道樂なり」

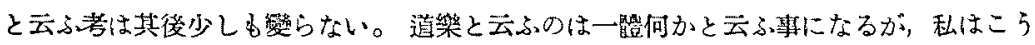
考人て居る。即ち「面白くてたまらないから夢中になつてやる事と思ふ。を机をやつて

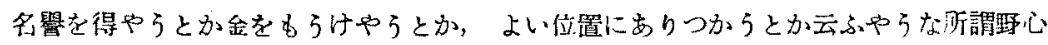

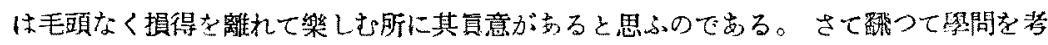
へて見ると何をやるにしてす面白くてたまらず营中になつてやると云ふ所に學問の本當 の姿が見られるのではないかと思はれる。して見ると學問は道樂なりと堑定しても少し

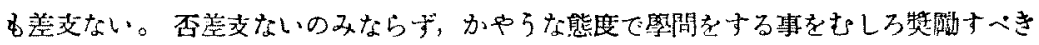

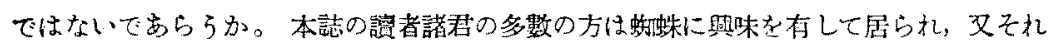

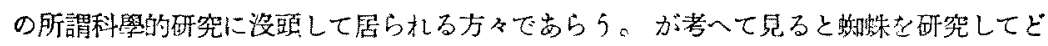
んな名礐が與へら机であらうか，又蝴蛛䒚研究したからと云つてよい位置が與へられ

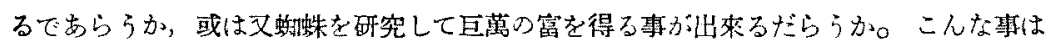

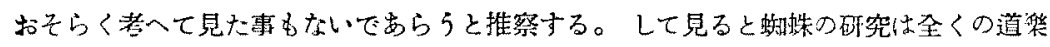
ですつて，最む票がべき境地に於て研究して居られるのである。人間の事棯から生きて

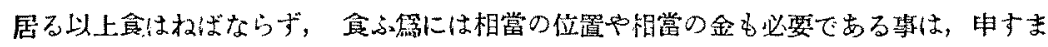
でもない。所が學問るする，本當に學問をすると云ふ事はかや万な方面にはむまり有利 な方法ではないるそれよりは役に立つ法律でもやつて官吏にな北ば威張れるだらうし，

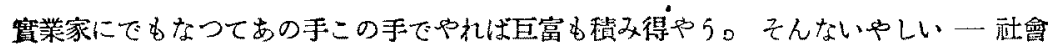
はからる事に熟心な人間をいやしい人間と云ふ一考は少しるなく蝴蛛の䂥究をやつて 居られる方々は抙く敬服に値するのである。之は皮肉でも何でもなく.學間は道樂なり」 そ粚定す机代當然得らるぺき歸結である。

學問とは何か？近頃生物學は著しく進步したと云ふ事は交に口に度々聞さ机て來た事 であつて私もさうだなと思つてるる。今日の生物學研究至は十數年前の動物學䀘究空や

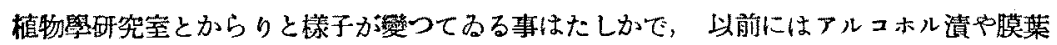




\section{(114)}

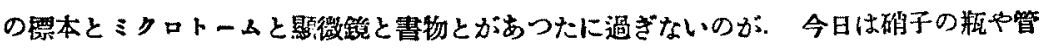
や画が林立して居り，電池や針金加所狭きまて配置されて居ると云つた有樟である。論

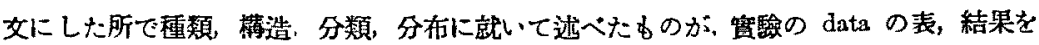

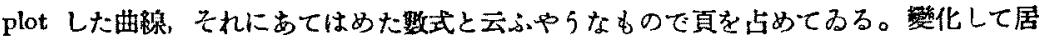
る事は確である。之を進步と云ふのである。そして近代生物學をやつてるると櫂する或

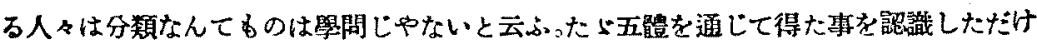
じゃ學問じやない。かやうな結果はかやうな原因に上つて起ると云ふ和又逆にかやうに

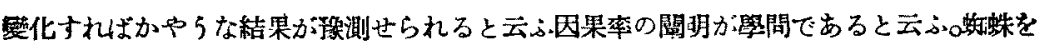

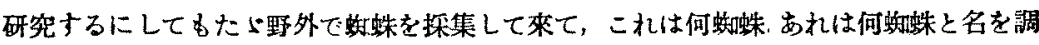
べる。或は未發表のすのであへば新種として名前を附けて發表する。或は又蜊蛛の胃は

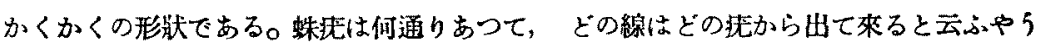
な事をやつてるとれは學問じやないと云ふ。何蜘蛛は何故に今日地球上に存在するか，

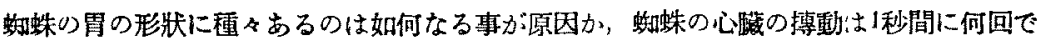
あつて，溫度を上げ下げすると如何に變化するか，そのdataを曲線に瞄くと數式はど れに當はまるか。と云ふやうな事を研究しなけれは祭問でないと云ふ。郎方學閣は自然

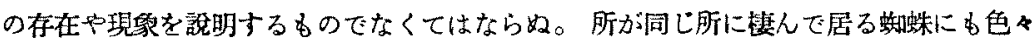

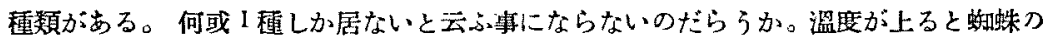
活動方盛んになる。何故か？その蜘蚝の原形質の活動がその溫度の時最も都合がよいか らである。それで說明になつて居るであら5か。蝴蛛の消化腺にはこれこれての䣼素があ つたと云ふ事と，この蜘怢の眼の配列はかくかくであると云か事とどこに一體逵ひがあ

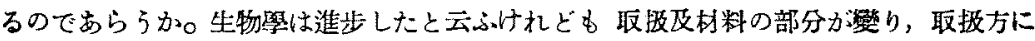
型化が來ただけで，物理學者や化祭者から見ればその極めて初步的な方法を借用して居

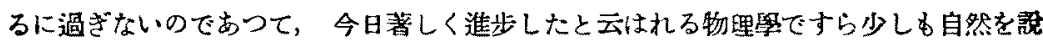
明して居ないので，かくかくの事䆩を記逑 describe して見るに過きないと云ふ哲學的考 察寸ら已に相當以前からあるのである。道樂なら何をやつて居たつて人の知つた事じや ない自分が面白くてたまらなければよいのではないか。魚屋のスさんか浪花節をうなつ

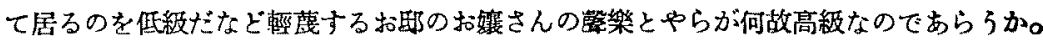

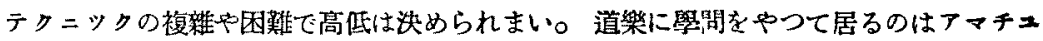
アだとよく云はれるっ 學間をやるのに黑人や素人るあるすのじやない。尤る學問みたい なすのを賣つて领の㞒にして居る人間を黑人と云ふのならこれは別問題だけれどす。 